\title{
THE CHALLENGES, RISKS AND PROSPECTS OF THE REALISATION OF THE MUSIC METHODOLOGY MODULE OF ONE - YEAR EDUCATION PROGRAMME
}

\author{
Guntars Bernāts ${ }^{1}$, Andrejs Mūrnieks² \\ ${ }^{1,2}$ University of Latvia, Latvia
}

\begin{abstract}
The reform of teachers' education commenced by the Ministry of Education and Science provides an opportunity to obtain a qualification as a teacher within one year, encompassing studies based in a working environment for those who already have higher education. The goal of the research is to identify the challenges, risks and perspectives of the realization of the module "Music methodology" of the study course "Integrated methods in Teaching Culture Understanding and Self-expression in Art" within the one-year study programme "Skolotajjs". The research compared study course plans in music teaching and choir work methodology at two Latvian higher education institutions, as well as at two foreign higher education institution, where a qualification as a music teacher at a comprehensive school can be attained. The research was undertaken based on an analysis of theoretical sources, providing an understanding about a synthesis of varying contemporary methodological approaches. It encompasses the acquisition of a knowledge of cultural history and the history of music, the style and future directions of popular music, desirably not just theoretically but practically as well, in the education of the students. The actualization of such study courses as music teaching methodology, the research process in music teaching, music history and stylistics, the psychology of music, conducting, choir/vocal ensemble work, methodology and music project management are important for the high quality and integrated acquisition of music teaching methodology.
\end{abstract}

Keywords: Perception of culture, music teacher, teaching methodology, teacher training.

To cite this article:

Bernāts, G. \& Mūrnieks, A. (2021). The Challenges, Risks and Prospects of the Realisation of the Music Methodology Module of One - Year Education Programme. Education. Innovation. Diversity, 2(2), 24-30.

DOI: https://doi.org/10.17770/eid2021.1.5428

\section{Introduction}

The second - level higher professional education study programme Skolotājs for attaining a teaching qualification within a year is being developed in collaboration with Daugavpils University and Liepāja University at the University of Latvia. The goal of the programme is to encourage the introduction of motivated teachers in schools with experience from other sectors.

The newly established study programme „The Teaching Power” is currently the only such study programme in the Baltics, therefore it was of utmost importance to choose for the present research stage the higher education institutions, in which a B.A. programme in music teaching/pedagogy is being implemented at present: in Latvia such institutions are the Jāzeps Vìtols Latvian Academy of Music and the Daugavpils University, in Lithuania - the Vytautas Magnus University, along with which the University of Music and Performing Arts Vienna represents the European values in culture education.

The goal of the research is to identify the challenges, risks and perspectives of the realization of the module "Music methodology" of the study course "Integrated methods in Teaching Culture Understanding and Self-expression in Art" within the one-year study programme "Skolotājs". The research compared study course plans in music teaching and choir work methodology at two Latvian higher education institutions, as well as at two foreign higher education institution, where a qualification as a music teacher at a comprehensive school can 
be attained. The research was undertaken based on an analysis of theoretical sources, providing an understanding about a synthesis of varying contemporary methodological approaches.

It is planned to continue the research in the future, focusing on the analysis of music teaching methodology modules separately within the framework of single year study programmes implementation.

The reform of teachers' education commenced by the Ministry of Education and Science (Latvijas Republikas Ministru kabineta tiesību aktu projekti, 2018) provides an opportunity to obtain a qualification as a teacher within one year, encompassing studies based in a working environment for those who already have higher education (Margeviča-Grinberga, 2021). This will allow for sector professionals to share their knowledge of other sectors in schools and to additionally obtain the skills required of a teacher which correspond with the new curriculum and approach of Skola 2030.

\section{Methods and materials}

The research is based on the comparison of the study programs created by music teachers working at four different universities. In the course of the present research the study programme plans of music teacher education were analysed in detail, along with the total number of credit points received, music teaching, specialised professional subject and collective music-making methodology study courses and their extent. The data gathered, as well as the knowledge, skills and competencies, that it is planned to acquire graduating from the study programmes of the four universities chosen for the comparison were compared to the planned study results from the implementation of the music methodology module of the study course "The integrated teaching methodology in the study field "Understanding of culture and selfexpression in art"" within the one-year study programme "Teacher".

Contemporary approaches to the study process will be used in the programme: learning in groups, teaching and learning leadership, situational and personalized learning etc.However, the following need to be clarified for such a programme to validly function, 1) factors, which influence the perception of music currently(in the context of global cultural processes), the cultural traditions of music in Latvia, as well as the main contradictions and problems in teaching music currently; 2) a comparison needs to be made of the existing experience at universities in creating the curriculum for teachers - together information about the required preconditions for the programme's implementation and 3) the main dimensions of the curriculumneed to be defined.

Global tendencies in culture reveal the co-existence of various local traditions, subcultures and tendencies, or multiculturalism (Giddens et. al., 2012), the dominance of mass culture in this coexistence and competition (Hofstede et. al., 2010; Kūle, 2006), the current trend of "living virtually" (Mirzojevs, 2017), especially among young people, the influence of entertainment, art and the music industry on ways of listening to music and the contribution of the creative industry (Caves, 2000).

The need to maintain the originality of each national culture (including traditional culture) arises alongside these and contrary to the tendencies mentioned. In the case of Latvia, this also means the values recognized by UNESCO, for example, the preservation and development of the Song Celebration traditions (Non-material Cultural Heritage). American anthropologist Clifford Geertz (reads in Latvian: Gīrcs) wrote: "the spiritual consciousness of a specific people is specifically formed, mainly through the more carefully developed and usually more public rituals as well ... these fully developed ceremonies could be called cultural performances" (Gīrcs, 1998, 116). In the case of Latvia, the Song Celebrations could be considered such a unifying performance. 
An equally important task for education is the need to motivate young people toward an ecologically responsible lifestyle (ergoto moderation, restraint, austerity and self-control), as well as to motivate them to a meaningful life within society. Nationally defined goals in values education is contained in Cabinet of Ministers' Regulations No, 480. "The Procedure for the Evaluation of Educative Guidelines and Information, Teaching Aids, Materials and Instruction and Educative Methods for Students" (Ministru kabineta noteikumi Nr. 480, 2016). In the educational process, the learner's understanding, responsible attitude and actions are promoted, which confirms the following values - the acquisition of human dignity, freedom, culture and the Latvian language. The authors of the research are convinced that without the awareness and acceptance of these values, neither cultural understanding nor self-expression in art is possible.

\section{Results and Discussions}

All of the mentioned trends and tasks have to be taken into account in the process for learning music. This brings additional high demands in preparing music teachers. The first task for preparing a new curriculum is to clarify the scope of basic problems in the principles for learning music.

As part of the first task, agreement has to be found on what we wish to achieve by teaching music at school. This is the goal (methodological) aspect. The next is the aspect of curriculum. What will be taught? Finally, the methodical aspect. How will it be taught?

A programme for educating teachers can be created depending on the types of answers to these three 3 problem issues. Two main approaches are possible when considering the goal of teaching music in schools of general education: a) to teach music or b) to teach about music.

In the first case, academic preparation that is sufficiently deep is required for teachers. Not just a knowledge of the history of music, but also practical skills for playing a musical instrument (one or more), to conduct a choir, to lead musical ensembles, to encourage and motivate self-led learning for students.

In the second case, in teaching only about music, some may think that a teacher's professional skills in music is not required, limiting this purely to the skill of talking about music, getting students interested in listening to music and the skill of analysing what they have heard.

The tradition in Latvian musical education, however, is to emphasise the first approach (to teach music). In an ideal version, both approaches could be combined: to both teach about music, as well as to teach music.

The next aspect, which must be borne in mind in creating a study programme, is the curriculum which will be taught in schools. This includes the skills, attitude and knowledge in developing a student's musical competence. However, the type of musical material that will be used in developing all the previously mentioned components is important. In formulating the problem in simple terms, there are two options: a) to teach what is topical (that which is heard the most frequently and more in Latvia, Europe and the Western cultural space, and that which is heard in the media consumed by most people in Latvia), b) to teach what is valuable (that which has stood the test of time and that which has crystallised over a longer period of time.

The fact that most young people "live" in this mass culture environment everyday cannot be ignored (Kūle, 2006). This is exactly why the learning of the topical one of music, style and genre must also be included in the curriculum.

But one cannot stop only at what is current and popular, as this would mean surrendering to the general consumer mentality. An opportunity should be provided for the student to also get to know and experience the wonder of classical music. The synthesis of both approaches, in turn, means including a knowledge of cultural history and the history of music, a learning 
about the style and direction of popular music, preferably not just theoretically, but also practically, in student education (Bautista et al, 2016).

Finally, the methodical aspect: how should it be taught? In this aspect too, there is its own antinomy or contrast between two approaches: emphasis mainly only a) on stimulating interest, or more b) on research. To teach in a simply pleasant or attractive way, or seriously, deeply and thoroughly? In the first approach, topicality, concreteness, situationism, compliance with contemporary assumptions and superficiality will dominate. The second approach will highlight the academic, the historic, criticism, comparison, analysis, synthesis and thoroughness. In the first approach, the study is like a game and attraction, while the second is like research, cogitation, and evaluation. A contemporary approach requires the synthesis of both extremes.

The goal of the study programme is to provide theoretical and practical preparation for the new teacher, through acquiring modern principles of teaching methodology, familiarization with cultural phenomena and works of art, analysis, interpretation and the development of experience through creative activity. Consequently, the fact that the acquisition of methodology is very important in the development of the new teacher can be concluded.

The following tasks should be undertaken to achieve the goal of the study programme:

- to provide theoretical and practical guidance to encourage competent activities by students, to improve their knowledge, skills, competence and creative ability;

- to promote an understanding of the theoretical content of the subject of culture and art;

- to provide knowledge and improve skills in modelling the teaching process, the choice of methodological techniques and the evaluation of student achievements.

The tasks formulated once again confirm what was concluded previously. Focusing on the number of lessons required to achieve the Music Teaching Methodology, the study course calendar plan provides information that 24 lessons are planned in the acquisition of the $\mathrm{M}$ module (Music Teaching Methodology).

The Jāzeps Vìtols Latvian Academy of Music's General Education Music Teacher professional bachelor study programme's study plan "Music Teaching and Choir Work Methodology" provides courses with 18 ECTS (Jāzeps Vītols Latvian Academy of Music, 2018).

The Daugavpils University's professional bachelor study programme Music prepares qualified and competitive Music Teachers for Playing Instruments or Solo Singing, or Choir Subjects, or for Schools of General Education. In the curriculum for the study programme, as in the Jāzeps Vìtols Latvian Academy of Music educational programme, music theory and history courses of 54 ECTS are planned, as well as professional specialization courses of 108 ECTS (Daugavpils University, 2019).

In the Vytautas Magnus University (Lithuania) second-level professional higher education study programme Music Pedagogy there were study courses of 42 ECTS provided for programme's specialization in conducting music ensembles (Vytautas Magnus University, 2020).

At the University of Music and Performing Arts in Vienna, in 4 years of full-time study in the qualifications for aGymnasium/Crafts School Music Teacher and Instrument Playing/Solo Singing Teacher or Gymnasium/Crafts School Music Teacher and Second Additional Subject Teacher study courses in the musical art field, 37 ECTS are acquired (University of Music and Performing Arts Vienna, 2019). 
Table 1 Comparison of music pedagogy study programs

\begin{tabular}{|c|c|c|c|}
\hline $\begin{array}{l}\text { Jāzeps Vītols Latvian } \\
\text { Academy of Music }\end{array}$ & Daugavpils University & $\begin{array}{l}\text { Vytautas Magnus } \\
\text { University }\end{array}$ & $\begin{array}{c}\text { University of Music } \\
\text { and Performing Arts in } \\
\text { Vienna }\end{array}$ \\
\hline $\begin{array}{c}\text { Music Teaching } \\
\text { methodology }-7,5 \\
\text { ECTS }\end{array}$ & $\begin{array}{c}\text { Choir subjects or } \\
\text { music teaching } \\
\text { methodology }-10,5 \\
\text { ECTS }\end{array}$ & $\begin{array}{c}\text { Music Lesson } \\
\text { Methodology - } 3 \text { ECTS }\end{array}$ & $\begin{array}{l}\text { Playing popular/folk } \\
\text { music in a musical } \\
\text { ensemble }\end{array}$ \\
\hline $\begin{array}{c}\text { Pre-School Music } \\
\text { Teaching Methodology } \\
-1,5 \text { ECTS }\end{array}$ & $\begin{array}{c}\text { Solo singing and vocal } \\
\text { work methodology }-9 \\
\text { ECTS }\end{array}$ & $\begin{array}{l}\text { Foundations of Music } \\
\text { Pedagogy - } 3 \text { ECTS }\end{array}$ & $\begin{array}{l}\text { 2. instrument and } \\
\text { practice }\end{array}$ \\
\hline $\begin{array}{c}\text { Rhythmic Teaching } \\
\text { Theory and Practice - } 3 \\
\text { ECTS }\end{array}$ & & $\begin{array}{c}\text { Didactics of music } \\
\text { technologies - } 5 \text { ECTS }\end{array}$ & $\begin{array}{c}\text { Conducting } \\
\text { 1.instrument/vocal }\end{array}$ \\
\hline $\begin{array}{c}\text { Arrangement }-1,5 \\
\text { ECTS }\end{array}$ & $\begin{array}{c}\text { Arrangement }-1,5 \\
\text { ECTS }\end{array}$ & $\begin{array}{c}\text { Ethnic culture and } \\
\text { music ensembles - } 5 \\
\text { ECTS }\end{array}$ & \\
\hline $\begin{array}{l}\text { Improvisation }-1,5 \\
\text { ECTS }\end{array}$ & & $\begin{array}{l}\text { Psychology of musical } \\
\text { activity - } 5 \text { ECTS }\end{array}$ & Multi-media work \\
\hline $\begin{array}{c}\text { School Choir Work } \\
\text { Methodology }-1,5 \\
\text { ECTS }\end{array}$ & $\begin{array}{l}\text { Choir science and } \\
\text { choir work } \\
\text { methodology }-3 \\
\text { ECTS }\end{array}$ & Conducting - 42 ECTS & Choir \\
\hline $\begin{array}{l}\text { Playing of Carl Orff's } \\
\text { Set of Instruments - I,5 } \\
\text { ECTS }\end{array}$ & & $\begin{array}{c}\text { Planning and } \\
\text { evaluation in music } \\
\text { education } 3 \text { ECTS }\end{array}$ & Movement and dance \\
\hline Total - 18 ECTS & Total-24 ECTS & Total - 66 ECTS & Total - 37 ECTS \\
\hline
\end{tabular}

The total planned number of credit points to be gained in the "Integrated Methods in Teaching Cultural Understanding of and Self-Expression in Art" study course is 4! This is a serious challenge for a high - quality educational process.

\section{Conclusions}

From researching the attainment of the study course offered at Latvian higher education institutions, as well as at foreign higher education institutions, it will be necessary to update the need for the following fundamental study courses for the high quality and integrated acquisition of music teaching methodology:

- $\quad$ music teaching methodology;

- $\quad$ research process in teaching (music teaching);

- $\quad$ music history and stylistics;

- $\quad$ psychology of music;

- $\quad$ conducting, choir/vocal ensemble work methodology;

- $\quad$ music project management.

The lack of the specific study courses is identified in the result of the comparative research of the study programmes carried out regarding the content of the new music methodology module. A risk arises of not reaching the programme goal in a high qualitative way without integrating the acquisition of the abovementioned study course in the curriculum of the "Integrated Methods in Teaching Cultural Understanding of and Self-Expression in Art" study course. 
As the result of this lack the students having completed the study course "The integrated teaching methodology in the study field "Understanding of culture and self-expression in art"" within the one-year study programme "Teacher" will have acquired a certain competency in only a single main approach mentioned in the theoretical study, namely - to teach about music. The main approach characteristic of the Latvian music education tradition - to teach music may be subjected to a limited, partial implementation due to the lack of appropriately thorough academic and professional education of the future teachers. Also the ideal unification of the two approaches - to teach music and to teach about music - may become unattainable due to the lack of sufficient erudition and theoretical knowledge of the young teachers.

\section{References}

Bautista, A., Yau, X., \& Wong J. (2016). High-quality music teacher professional development: a review of the literature. Music education research, Volume 19, Issue 4 DOI: doi.org/10.1080/14613808.2016.1249357

Caves, R. E. (2000). Creative Industries: Contracts between Art and Commerce. Harvard University Press.

Daugavpils University. (2019). Self-evaluation report for the study direction "Art" for 2018/2019. study year. The Faculty of Music and Arts. Retrieved from https://du.lv/wpcontent/uploads/2020/04/Maksla_pasnovertejuma-zinojums_2018_2019.pdf

Giddens, J., Nortth, S., Carlson-Sabelli, L., Rogers, E., \& Fogg, L. (2012). Using a virtual community to enchance cultural awarness. - Journal of Transcultural Nursing: Official Journal of the Transcultural Nursing Society, 23(2); 198- 204.

Gīrcs, K. (1998). Kultūru interpretācija. [Clifford Geertz, The Interpretation of Cultures]. Rìga: izdevniecība AGB.

Hofstede, G., Hofstede, G.J.,Minkov, M. (2010). Cultures and Organizations: Software of the Mind. Intercultural Cooperation and Its Importance for survival. Retrieved from https://eedu.nbu.bg/pluginfile.php/900222/mod_resource/content/1/G.Hofstede_G.J.Hof stede_M.Minkov\%20-\%20Cultures\%20and\%20Organizations\%20\%20Software\%20of\%20the\%20Mind\%203rd_edition\%202010.pdf

Jāzeps Vītols Latvian Academy of Music. (2018). Professional bachelor's study programme Music Teacher Study plan. Retrieved from https://www.jvlma.lv/studijas/aktualiestudiju-plani-1/studiju-virziens-izglitiba-un-pedagogija

Kūle, M. (2006). Eirodzīve: formas principi, izjūtas. [Eurolife: forms, principles, feelings]. Rīga: LU FSI.

Latvijas Republikas Ministru kabineta tiesību aktu projekti. (2018). Informatīvais ziņojums "Priekšlikumi konceptuāli jaunas kompetencēs balstītas izglītības prasībām atbilstošas skolotāju izglītības nodrošināšanai Latvijā". [Informative report "Proposals for the provision of conceptually new competence-based teacher education in Latvia"]. Retrieved from http://tap.mk.gov.lv/lv/mk/tap/?pid=40444622\&mode=mk\&date=201801-09

Margeviča-Grinberga, I. (2021). Skolotāja profesionālā kompetence mūsdienu mainīgajā, neparedzamajā pasaulē. [Teacher's professional competence in today's changing, unpredictable world] Pedagogu profesionālā lietpratība - evolūcija vai revolücija/TAGAD Retrieved from https://maciunmacies.valoda.lv/wpcontent/uploads/2021/03/TAGAD_2021_WEB_2021.pdf

Ministru kabineta noteikumi Nr. 480. (2016). Izglītojamo audzināšanas vadlīnijas un informācijas, mācību līdzekḷu, materiālu un mācību un audzināšanas metožu izvērtēšanas $k \bar{a} r t \bar{\imath} b a$. [The Procedure for the Evaluation of Educative Guidelines and Information, Teaching Aids, Materials and Instruction and Educative Methods for Students, C.M.R., 
c. 480]. Retrieved from https://likumi.lv/ta/id/283735-izglitojamo-audzinasanasvadlinijas-un-informacijas-macibu-lidzeklu-materialu-un-macibu-un-audzinasanasmetozu-izvertesanas

Mirzojevs, N. (2017). Kā raudzìties uz pasauli. [How to See the World]. Rīga: Jāna Rozes apgāds. Nemateriālais kultūras mantojums.

University of Music and Performing Arts Vienna. (2019). Framework curriculum for the bachelor's degree in teaching.Retrieved from https://www.mdw.ac.at/studienplaene/?stNR=33250\&stArt=cur

Vytautas Magnus University. (2020). Subject pedagogy study plan. Retrieved from https://www.vdu.lt/lt/study/program/subject/341/ 